\title{
RANCANG BANGUN SOLAR DRYER UNTUK MENINGKATKAN KUALITAS REFUSE DERIVED FUELS (RDF) SEBAGAI BAHAN BAKAR ALTERNATIF DI KILN BURNER INDUSTRI SEMEN
}

\author{
Q A M O Arifianti ${ }^{1}, \mathrm{M}$ R Abidin², E F Nugrahani ${ }^{3}, \mathrm{~K}$ K Ummatin ${ }^{4}$ \\ 1,2,3,4 Universitas Internasional Semen Indonesia, Kompleks PT. Semen Indonesia (Persero) Tbk. \\ Jl. Veteran, Gresik Jawa Timur, 61122 \\ (031) 3985482 \\ qurrotin.arifianti@uisi.ac.id
}

\begin{abstract}
To utilize the municipal solid waste (MSW), PT Semen Indonesia has a program to convert waste into three useful products. One of the product is named Refuse Derived Fuel (RDF). The RDF has claimed that it had a caloric value about $5178 \mathrm{kcal} / \mathrm{kg}$. However, currently, RDF could not be used for the combustion process in the cement kiln since RDF has higher moisture content and lower caloric value. In this research, a solar dryer with greenhouse type is designed to reduce the moisture content. The performance is tested using two variations and compared to the conventional method. The variations are a solar dryer with one fan and with no fan. The general results show that variation with one fan has the highest drying rate among all. There is a significant reduction of moisture content after drying process using a solar dryer. The moisture content could be reduced to $16.25 \%$ and $17 \%$ using one fan and no fan, respectively. Furthermore, variation with 1 fan has higher solar dryer efficiency than that of one fan.
\end{abstract}

Keywords: a solar dryer, greenhouse type, Refuse Derived Fuel (RDF)

\section{PENDAHULUAN}

PT Semen Indonesia (Persero) Tbk merupakan perusahaan BUMN yang memiliki sebuah program pengolahan sampah bersama dengan Pemerintah Kabupaten Gresik, yang bernama program Waste to Zero (WTZ) di TPA Ngipik. Pengolahan sampah kota tersebut dilakukan dengan mengolah sampah menjadi tiga produk, yaitu sampah organik, bahan bakar alternatif/ Refuse Derived Fuel (RDF), dan batubatuan. Bahan bakar alternatif yang dihasilkan dalam plant pengolahan sampah tersebut akan dimanfaatkan menjadi bahan bakar subtitusi batu bara di kiln burner PT Semen Indonesia. Nilai kalor yang dimiliki RDF tersebut sebesar sebesar $5178 \mathrm{kcal} / \mathrm{kg}$ [1].

Program pengolahan sampah yang dilakukan oleh PT Semen Indonesia dianggap sangat menguntungkan bagi lingkungan karena dapat mengurangi jumlah sampah dan juga dapat mengurangi emisi gas $\mathrm{CO}_{2}$. Program tersebut diharapkan dapat terus berjalan sesuai dengan rencana untuk jangka panjang. Namun, terdapat permasalahan pada salah satu produk pengolahan sampah, yaitu rendahnya kualitas
RDF. Kadar air yang seharusnya terkandung dalam RDF tersebut adalah sekitar 10\%, tetapi pada kenyataannya, kadar air RDF mencapai 30-40\%. Padahal RDF tersebut akan mensubtitusi $\pm 10 \%$ dari total batu bara pada kiln.

Menurut hasil observasi dari pihak Biro Pengelolaan Lingkungan, terdapat beberapa kendala yang mempengaruhi kualitas dan kuantitas RDF tersebut yaitu bahan baku RDF mengandung kadar air tinggi, mesin tidak sesuai dengan rancangan atau tidak sesuai kapasitas awal, dan kadar air yang terkandung pada RDF tinggi. Untuk meningkatkan kualitas RDF, dibutuhkan sebuah alat pengering yang digunakan untuk mengurangi kadar air.

Dengan mempertimbangkan area tempat pengolahan sampah yang cukup besar dan radiasi matahari yang cukup tinggi di kota Gresik, maka sistem pengering RDF yang diusulkan akan berbasis energi surya. Terdapat dua metode pengeringan dengan sinar matahari, yaitu pengeringan alami dan mekanis. Metode pertama hanya mengandalkan radiasi sinar matahari, seperti 
pengeringan terbuka. Metode tersebut industri makanan. Untuk mensirkulasikan merupakan metode yang sudah lama udara, sembilan kipas dengan daya $15 \mathrm{~W}$ dimanfaatkan untuk mengeringkan bahan digunakan. Hasil penelitian menunjukkan waktu pangan, seperti ikan dan hasil pertanian dan pengeringan lebih cepat 2-3 hari dari tidak membutuhkan banyak biaya. Namun, hal pengeringan konvensional. M. M. Morad [7] yang perlu dipertimbangkan, pengeringan ini membandingkan dua mode operasi kipas pada rentan akan bakteri dan sangat tergantung alat pengering dengan sistem greenhouse, dengan cuaca. Untuk meminimalisir yaitu secara kontinyu dan periodik. Mode kekurangan tersebut, metode konvensional ini periodik dapat meningkatkan laju pengeringan dapat dikombinasikan dengan penambahan sebesar $22.78 \%$ atap dan dinding penutup.

Penelitian yang bertujuan untuk

F.K. Forson dkk [2] merancang alat meningkatkan kualitas RDF dilakukan dengan pengering singkong dengan mengadopsi menggunakan alat pengering mekanis prinsip mixed-mode natural convection di dalam bertenaga matahari. Pengering tersebut struktur tertutup. Hasil penelitian menunjukkan berbentuk semi-silinder dengan tipe bahwa kadar air singkong dapat berkurang dari greenhouse, memiliki tempat pengering dengan $67 \%$ sampai $17 \%$ dengan efisiensi pengeringan tipe batch. Atap pengering terbuat dari sebesar $12.5 \%$. S. Maiti dkk [3] menambahkan fiberplastik tembus cahaya yang berfungsi reflektor pada alat pengering skala kecil yang untuk mentransferkan cahaya matahari masuk telah dirancang, sehingga meningkatkan ke dalam sebuah ruang pengering sehingga efisiensi pengeringan dari $40 \%$ ke $58.5 \%$. J. dapat meningkatkan suhu pengeringan. Selain Banout dkk [4] membandingkan dua jenis itu, alat pengering dilengkapi dengan fan. pengeringan (langsung dan tidak langsung) Penelitian ini dilakukan di Biro Pengelolaan terhadap komposisi minyak yang terkandung Lingkungan, yang bertempat di TPA Ngipik dalam tumbuhan Sacha Culantro. Mereka Gresik. Pada penelitian ini, kadar air yang menemukan jenis pengeringan secara tidak diturunkan akan disesuaikan dengan standar langsung merupakan teknik yang cocok untuk yang telah dikeluarkan oleh PT. Semen tanaman tersebut karena mendekati komposisi Indonesia (Persero) Tbk. yaitu sebesar 10kimia yang diinginkan.

Sedangkan metode kedua, system pengeringan tidak hanya mengandalkan panas matahari, tetapi terdapat penambahan alat untuk meningkatkan laju pengeringan. Hasil penelitian sebelumnya menunjukkan bahwa sistem pengering energi surya mekanis telah banyak diaplikasikan untuk mengurangi kadar air suatu material serta memiliki nilai ekonomis yang tinggi. N.S. Rathore dan N.L. Panwar [5] menggunakan pengering tipe solar tunnel dengan bentuk hemi silinder untuk mengeringkan kapas bedah. Alat pengering tersebut dilengkapi dengan kipas yang digunakan untuk mengalirkan udara dan mempercepat penguapan kadar air. Hasil evaluasi menunjukkan terjadi pengurangan kadar kelembaban yang signifikan dari $40 \%$ sampai 5\% dengan waktu pengeringan 7-8 jam.

S. Janjai [6] mengembangkan alat $20 \%$.

\section{TINJAUAN PUSTAKA}

Laju Pengeringan RDF

Laju pengeringan dapat dihitung dengan menggunakan persamaan sebagai berikut:

$$
\frac{d W}{d t}=\frac{w_{t}-w_{t+1}}{t} \times 100 \%
$$

keterangan:

$\begin{array}{ll}\frac{d w}{d t} & \text { : laju pengeringan (\%/jam) } \\ w_{t} & \text { : berat benda yang mengandung air } \\ & \text { ditimbang pada waktu ke } \mathrm{t}(\mathrm{kg}) \\ w_{t+1} & \text { : berat benda yang mengandung air } \\ & \text { ditimbang pada waktu ke } \mathrm{t}+1(\mathrm{~kg}) \\ t & \text { : waktu pengeringan (jam) }\end{array}$

Kandungan Air (moisture content)

Besarnya kandungan air dalam suatu material pengering tipe greenhouse skala kecil untuk dapat diekspresikan dalam basis kering dan 
basah. Berikut adalah perhitungan kandungan air pada basis kering [8]:

$$
\begin{aligned}
& M_{w b}=\frac{W_{o}-W_{d}}{W_{o}} \\
& \% M_{w b}=M_{w b} \times 100
\end{aligned}
$$

Sedangkan perhitungan pada basis basah dapat dilihat pada persamaan berikut [9]:

$$
\begin{gathered}
M_{d b}=\frac{W_{o}-W_{d}}{W_{d}} \\
\% M_{d b}=M_{d b} \times 100
\end{gathered}
$$

Keterangan:

$W_{o}$ : berat awal dari produk yang belum dikeringkan

$W_{d}$ : berat produk kering

\section{Analisa Energi pada Solar Dryer}

Alat pengering surya menerima radiasi matahari dan mengubah radiasi tersebut menjadi panas yang berguna untuk menguapkan kadar air suatu material. Rumus keseimbangan energi yang digunakan untuk mengevaluasi performansi termal pada sistem alat pengering adalah sebagai berikut [9] [10] [11]:

$$
Q=Q_{c}+Q_{e v}+Q_{l o s s}
$$

Energi surya yang diserap oleh alat pengering (Q) dapat dihitung dengan menggunakan parameter radiasi matahari yang masuk melewati cover alat pengering dan luasan permukaan alat pengering. Persamaannya dapat diekspresikan sebagai berikut:

$$
Q=R \cdot A_{d}
$$

Selanjutnya, panas berguna yang dihasilkan oleh pengering dapat dihitung dengan menggunakan persamaan berikut:

$$
\begin{aligned}
& Q_{c}=m_{u} \cdot C_{p} \cdot\left(T_{u i}-T_{u o}\right) \\
& m_{u}=V \cdot A \cdot \rho
\end{aligned}
$$

Total energi termal yang terdapat dalam sistem meliputi penjumlahan panas sensibel yang digunakan untuk menaikkan temperatur bahan dan panas laten yang digunakan untuk menguapkan kandungan air di dalam bahan, sehingga persamaan dapat dirumuskan sebagai berikut:

$$
\begin{aligned}
Q_{e v} & =q_{\text {laten }}+q_{\text {sensibel }} \\
Q_{e v} & =\frac{\left[L_{h} \cdot m_{w}+m_{i} \cdot C_{p m} \cdot\left(T_{u i}-T_{m}\right)\right]}{3.6} \\
m_{w} & =\frac{m_{i}\left(M_{i}-M_{f}\right)}{100-M_{f}}
\end{aligned}
$$

Rugi-rugi termal dari bagian dalam alat pengering ke luar dapat dihitung dengan menggunakan persamaan berikut:

$$
Q_{e v}=U_{o} \cdot A_{c} \cdot\left(T_{a i}-T_{a o}\right)
$$

Persamaan di atas dapat digunakan sebagai dasar untuk menghitung efisiensi sistem pengering yang digunakan untuk mengukur keseluruhan efektivitas dari sistem pengeringan. Efisiensi alat pengering dapat diperoleh dari persamaan berikut:

$$
\eta_{d}=\frac{m_{w} L+Q_{e v}}{R \cdot A_{d}+P_{f}}
$$

\section{Desain Pengering Sebelumnya}

Untuk memberikan gambaran tentang desain alat pengering RDF, berikut adalah ringkasan rancangan yang pernah dihasilkan oleh peneliti sebelumya.

1. Tipe penutup parabola dan tambahan permukaan panel surya

K. Jitjack dkk [12] membandingkan dua jenis alat pengering greenhouse, yaitu dengan bentuk parabola (PG) seperti pada gambar 1a dan bentuk parabola dengan tambahan luasan panel (PGEP) seperti pada gambar 1b. Alat pengering tersebut digunakan untuk mengeringkan lembaran karet. Dimensi prototipe $P G$ adalah $2 \times 3.5 \times 1.5 \mathrm{~m}^{3}(\mathrm{~L} \times \mathrm{P} \times \mathrm{T})$, sedangkan PGEP sebesar $3 \times 3.5 \times 1.5 \mathrm{~m}^{3}$ $(L \times P \times T)$. Penutup greenhouse terbuat dari lembaran polikarbonat. Hasil eksperimen menunjukkan bahwa temperatur ruangan PGEP lebih tinggi $5^{\circ}$ dibandingkan dengan PG 


\begin{tabular}{|c|c|c|c|}
\hline$m_{u}$ & laju alir udara $(\mathrm{kg} / \mathrm{s})$ & $A$ & $\begin{array}{l}\text { luas penampang jendela alat } \\
\text { pengering }\left(\mathrm{m}^{2}\right)\end{array}$ \\
\hline$m_{w}$ & $\begin{array}{l}\text { massa air yang menguap selama } \\
\text { proses dehidrasi }(\mathrm{kg})\end{array}$ & $A_{d}$ & $\begin{array}{l}\text { total luas permukaan alat pengering } \\
\left(\mathrm{m}^{2}\right)\end{array}$ \\
\hline$m_{i}$ & $\begin{array}{c}\text { massa material di dalam alat } \\
\text { pengering }(\mathrm{kg})\end{array}$ & $A_{c}$ & $\begin{array}{l}\text { luas permukaan cover fiber plastik } \\
\left(\mathrm{m}^{2}\right)\end{array}$ \\
\hline$M_{i}$ & $\begin{array}{l}\text { kadar air awal material, \% basis } \\
\text { basah }\end{array}$ & $V$ & kecepatan udara (m/s) \\
\hline$M_{f}$ & $\begin{array}{l}\text { kadar air akhir material, \% basis } \\
\text { basah }\end{array}$ & $\rho$ & massa jenis air $\left(\mathrm{kg} / \mathrm{m}^{3}\right)$ \\
\hline$C_{p}$ & kalor spesifik udara $\left(\mathrm{J} / \mathrm{kg}^{\circ} \mathrm{C}\right)$ & $L_{h}$ & $\begin{array}{l}\text { kalor laten penguapan air dalam } \\
\text { material }(\mathrm{kJ} / \mathrm{kg})\end{array}$ \\
\hline$C_{p m}$ & kalor spesifik material $\left(\mathrm{J} / \mathrm{kg}^{\circ} \mathrm{C}\right)$ & $L$ & $\begin{array}{l}\text { kalor laten penguapan air pada } \\
\text { temperatur udara luar }(\mathrm{kJ} / \mathrm{kg})\end{array}$ \\
\hline$T_{m}$ & temperatur material $\left({ }^{\circ} \mathrm{C}\right)$ & $U_{o}$ & $\begin{array}{l}\text { koefisien total perpindahan panas } \\
\left(\mathrm{W} / \mathrm{m}^{2}{ }^{\circ} \mathrm{C}\right)\end{array}$ \\
\hline$T_{u i}$ & $\begin{array}{l}\text { temperatur udara di dalam alat } \\
\text { pengering }\left({ }^{\circ} \mathrm{C}\right)\end{array}$ & $P_{f}$ & Daya fan (W) \\
\hline$T_{u o}$ & $\begin{array}{l}\text { temperatur ambien di luar alat } \\
\text { pengering }\left({ }^{\circ} \mathrm{C}\right)\end{array}$ & $R$ & total flux radiasi matahari $\left(\mathrm{W} / \mathrm{m}^{2}\right)$ \\
\hline
\end{tabular}

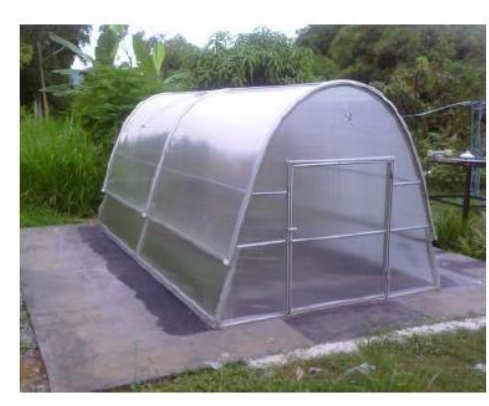

(a)

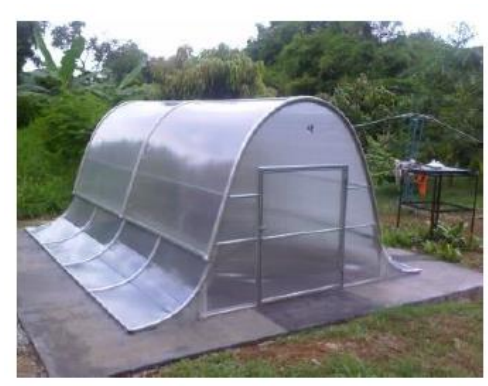

(b)

Gambar 1. Alat Pengering (a) Parabolic Greenhouse (PG) (b) Parabolic Greenhouse dengan tambahan luasan panel

2. Tipe alat pengering dengan mengadopsi sistem greenhouse dan penambahan fan

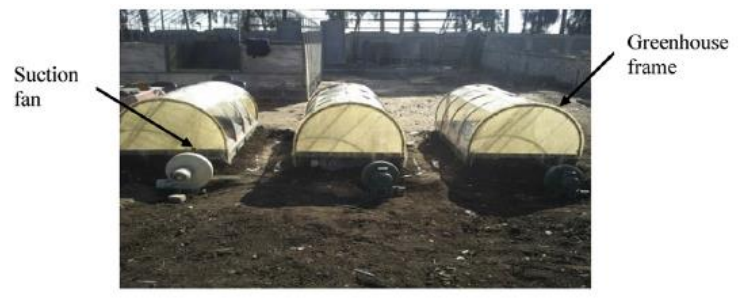

Gambar 2. Pengering Tenaga Surya dengan Sistem Terowongan

M. M Morad dkk [6] merancang alat pengering untuk mengeringkan daun peppermint dengan tambahan dua fan seperti yang terlihat pada Gambar 2. Dengan laju alir udara yang dihasilkan oleh fan sebesar 2.10 $\mathrm{m}^{3} / \mathrm{min}$, waktu pengeringan dapat berkurang menjadi 9 jam. Dimensi solar dryer yang dirancang adalah $2000 \mathrm{~mm} \times 1000 \mathrm{~mm} \times 800$ $\mathrm{mm}(\mathrm{P} \times \mathrm{L} \times \mathrm{T})$. Bahan penutup terbuat dari lembaran plastik dengan ketebalan $200 \mu \mathrm{m}$. Fan digerakkan dengan motor $0.5 \mathrm{hp}(0.37 \mathrm{~kW}$ pada $3000 \mathrm{rpm}$ ).

3. Tipe alat pengering greenhouse dengan warna permukaan utara buram.

O. Prakash dan A. Kumar [13] merancang alat pengering greenhouse dengan skala laboratorium dan dinding utara berwarna 
buram. Selama percobaan, alat pengering sangat memungkinkan untuk diterapkan adalah menghadap ke arah timur-barat untuk dengan menggunakan solar dryer. Selanjutnya, mendapatkan radiasi matahari maksimum. tahap fabrikasi solar dryer akan dilakukan. Atap alat pengering memiliki kemiringan Pada tahapan ini, dilakukan pembelian dan sebesar $23^{\circ}$. Terdapat dua modifikasi lantai alat pemasangan komponen-komponen penyusun pengering, modifikasi pertama yaitu lantai solar dryer. Kemudian percobaan mulai tanpa penutup, sedangkan modifikasi kedua dilaksanakan dengan menggunakan bahan menggunakan penutup. Gambar 3 baku RDF sebanyak $20 \mathrm{~kg}$ dan variasi mode menunjukkan hasil rancangan alat pengering. operasi kipas. Hasil dari percobaan dianalisa, Hasil percobaan menunjukkan terdapat terutama dari hasil kandungan air.

kenaikan temperatur ruangan yang signifikan dan penurunan kelembapan relatif pada greenhouse dengan penutup.
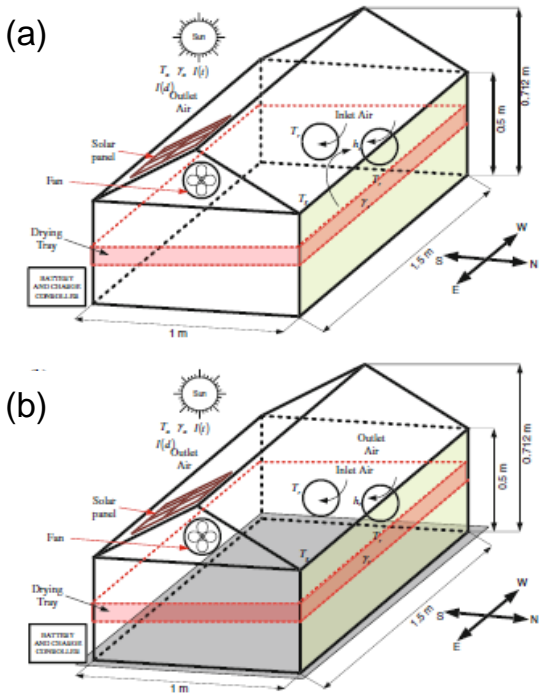

Gambar 3. Diagram Skema Alat Pengering Greenhouse yang Dimodifikasi (a) Lantai tanpa Cover (b) Lantai dengan Cover

\section{METODOLOGI PENELITIAN}

Penelitian yang dilakukan merupakan bagian dari upaya peningkatan kualitas salah satu produk olahan sampah di kota Gresik, yaitu Refuse Derived Fuel (RDF). Penelitian diawali dari identifikasi masalah yang muncul di dalam pengolahan RDF, yaitu kadar air yang mencapai 30\%. Dari permasalahan tersebut, solusi ilmiah akan dicari berdasarkan hasil studi literatur yang dilakukan dan disesuaikan dengan potensi yang ada di sekitar tempat produksi RDF.

Tempat produksi RDF berada di lahan yang luas dan disinari oleh matahari dengan intensitas yang tinggi. Berdasarkan hasil studi literatur awal yang dilakukan, solusi yang

\section{Metode Pengumpulan Data}

Terdapat dua metode pengumpulan data dalam penelitian ini, studi dokumen dan observasi. Studi dokumen yang dilakukan berkaitan dengan laporan hasil laboratorium kondisi RDF (nilai kalor dan kandungan air) milik PT Semen Indonesia. Sedangkan, untuk metode observasi, pengusul akan mengamati fenomena yang terjadi secara langsung dengan melakukan serangkaian tahapan percobaan. Percobaan akan dilakukan di area tempat penampungan akhir (TPA) sampah di kota Gresik. Variasi yang ada di dalam percobaan adalah variasi penggunaan fan (1 fan beroperasi, 2 fan beroperasi, dan tanpa fan). Untuk setiap variasi, dilakukan pengulangan sebanyak 2 kali.

\section{Desain Eksperimen}

Tabel 1 menunjukkan desain eksperimen yang berisi informasi data input dan output. Data input terdiri dari variable tetap dan bebas. Variabel tetap pada percobaan solar dryer RDF adalah desain solar dryer dan bahan baku RDF. Massa bahan baku RDF yang digunakan adalah sebesar $20 \mathrm{~kg}$. Sedangkan variabel bebasnya adalah variasi mode operasi fan, yaitu 1 fan beroperasi dan fan tidak beroperasi.

Untuk data output, data terbagi menjadi dua bagian, data yang diukur dan data yang dihitung. Data yang diukur meliputi temperatur udara di dalam dan di luar alat pengering, temperatur RDF, massa RDF, kadar air awal dan akhir RDF, iradiasi, kecepatan angin, kecepatan udara, dan daya fan. Sedangkan data yang dihitung adalah luasan permukaan alat pengering dan jendela, laju alir udara (persamaan 9), kalor spesifik udara dan 
material (dihitung berdasarkan temperatur), laju pengering (persamaan 14), parameter pengeringan (persamaan 1), efisiensi sistem selanjutnya dapat dilihat di Tabel 1.

Tabel 1. Desain Eksperimen

\begin{tabular}{|l|l|l|l|}
\hline \multicolumn{2}{|c|}{ Input Data } & \multicolumn{2}{c|}{ Ouput Data } \\
\hline Variabel Tetap & Variabel Bebas & Data yang Diukur & Data yang Dihitung \\
\hline - Desain solar & - Penggunaan & - Temperatur udara & - Luasan permukaan alat \\
dryer & variasi exhaust & di dalam dan di & pengering, jendela \\
- Bahan baku & fan & luar alat & - Laju alir udara \\
RDF & & pengering & - Kalor spesifik udara dan \\
& & - Temperatur RDF & material \\
& & di dalam alat & - Massa jenis udara \\
& & pengering & - Kalor laten penguapan \\
& & - Massa RDF & air pada RDF dan \\
& & - Kadar air awal & temperatur udara luar \\
& & dan akhir RDF & - Laju Pengeringan \\
& & - Iradiasi & - Koefisien total \\
& & - Kecepatan angin & perpindahan panas \\
& & - Kecepatan udara & - Efisiensi sistem \\
& & - Daya fan & pengering \\
\hline
\end{tabular}

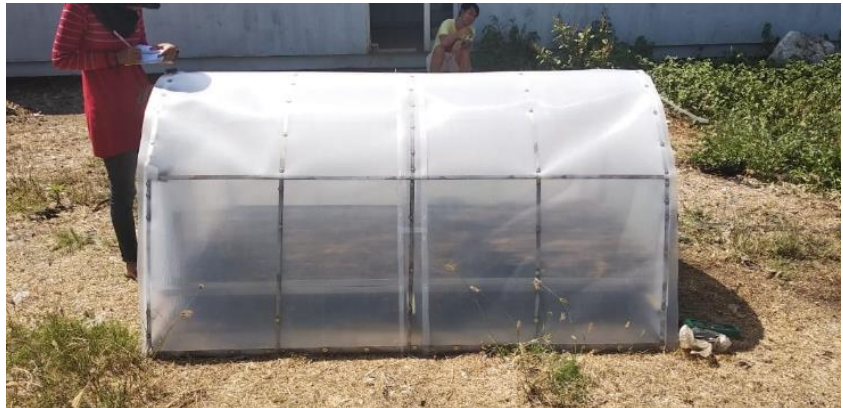

(a)

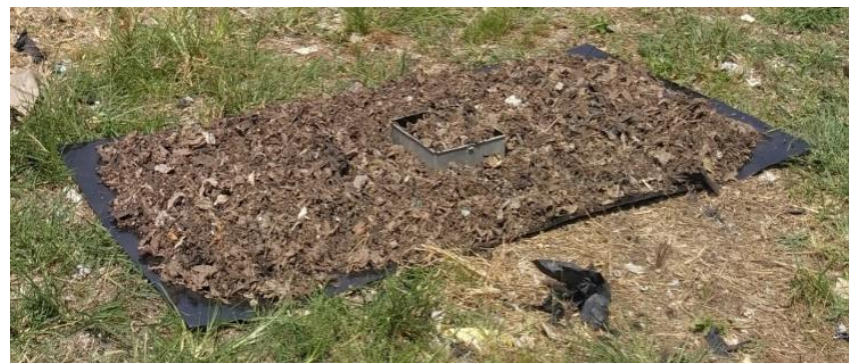

(b)

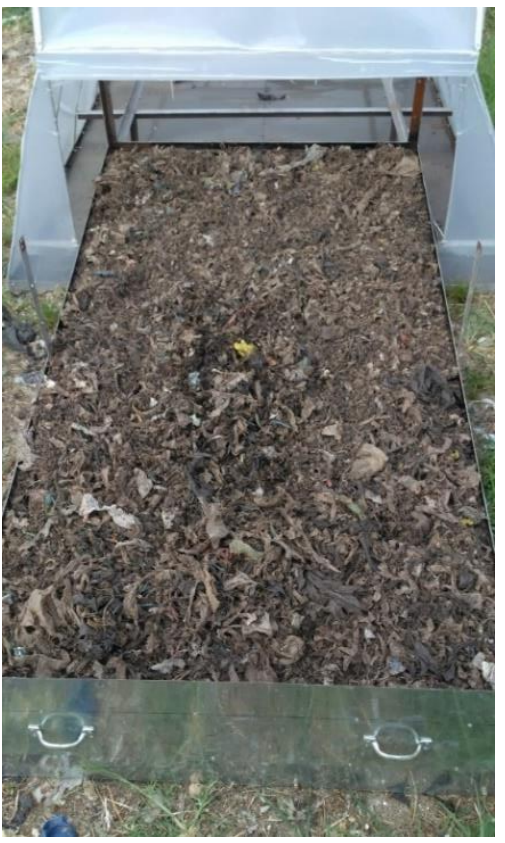

(c)

Gambar 4. Proses Pengeringan RDF (a) Alat Solar Dryer (b) Konvensional (c) Alas Pengering selama 6 jam 
Desain alat pengering ini berbentuk semisilinder dimana memiliki ruang pengeringan di dalamnya dan memiliki 1 buah fan berdaya sebesar 0,6 Ampere yang terletak di sisi belakang greenhouse tersebut. Atap dan dinding yang menyelimuti solar dryer tersebut terbuat dari fiber glass plastik yang memiliki transmisivitas panas sampai $95 \%$ dan memberikan kemudahan dalam pemasangan karena memiliki sifat lentur.

Alat pengering tenaga surya memiliki alas pengeringan berupa plat alumunium dengan ketebalan $\mathrm{w}=0.005 \mathrm{~m}, \mathrm{p}=1,8 \mathrm{~m}$ dan $\mathrm{I}=1 \mathrm{~m}$, Plat dengan bahan alumunium dipilih karena bahan alas pengering tersebut tahan terhadap korosi dan alumunium merupakan penyerap panas terbaik dibandingkan dengan material logam lainnya. Untuk alas dari greenhouse terbuat dari seng. Pintu dari greenhouse ini berbentuk persegi panjang untuk mempermudah keluar-masuk material yang akan dikeringkan.

Gambar 4a menunjukkan hasil pembuatan alat pengering tenaga surya. Pengeringan dengan metode konvensional dilakukan dengan meletakkan RDF di permukaan seng berwarna hitam seperti pada Gambar 4b. Untuk memudahkan proses peletakkan dan pengambilan RDF, maka alas pengering di dalam alat pengering menggunakan sistem laci seperti pada Gambar 4c.

\section{Iradiasi Matahari yang dipancarkan}

Sumber energi yang paling utama dalam proses pengeringan adalah sinar matahari. Sinar matahari menghasilkan radiasi inframerah yang ditangkap oleh permukaan pengering. Panas radiasi yang dihasilkan terjebak di dalam alat pengering sehingga suhu di dalam ruangan meningkat. Untuk mengetahui seberapa besar iradiasi yang dipancarkan dengan bantuan alat berupa multimeter 5 in 1 yang terdapat sensor pengkuran cahaya. Output dari alat bantu adalah luxmeter dan dikonversikan ke $\mathrm{W} / \mathrm{m}^{2}$ dengan dibagi sebesar 683. Hasil perhitungan konversi luxmeter ke W/m2 seperti dibawah ini. Cahaya matahari variasi tanpa fan

pukul $09.00: 54188,537$ lux
$683 \mathrm{lux}=1 \mathrm{~W} / \mathrm{m}^{2}$

Konversi : lux/683

$$
\begin{aligned}
& =54188,537 \text { lux } / 683 \\
& =79,34 \mathrm{~W} / \mathrm{m}^{2}
\end{aligned}
$$

Hasil pengukuran yang didapatkan dapat dilihat pada Gambar 5. Pada percobaan tanpa menggunakan fan, iradiasi matahari yang dihasilkan tertinggi pukul 12.00 sebesar 79,34 $\mathrm{W} / \mathrm{m}^{2}$ dan terendah pada pukul 15.00 sebesar $51,30 \mathrm{~W} / \mathrm{m}^{2}$. Pada percobaan menggunakan variasi $1 \mathrm{fan}$, nilai iradiasi matahari tertinggi pada pukul 12.00 sebesar $77,02 \mathrm{~W} / \mathrm{m}^{2}$, terendah pada pukul 09.00 yaitu $50.68 \mathrm{~W} / \mathrm{m}^{2}$. Pada percobaan dengan pengeringan konvensional, nilai iradiasi matahari tertinggi sebesar $77.08 \mathrm{~W} / \mathrm{m}^{2}$ pada pukul 12.00 , dan terendah pada pukul 15.00 sebesar 49.57 $\mathrm{W} / \mathrm{m}^{2}$. Dari hasil yang didapatkan nilai rata-rata iradiasi tertinggi pada percobaan tanpa menggunakan fan dan terendah pada percobaan memakai 1 fan.

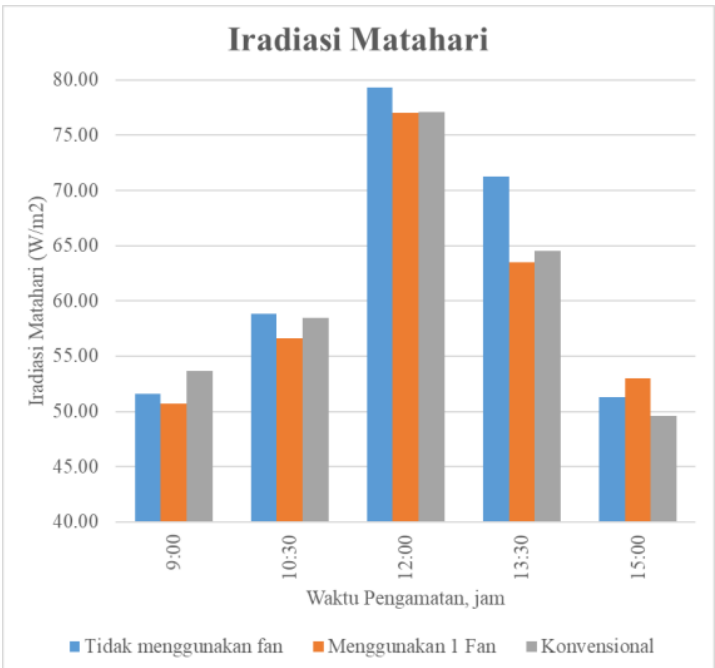

Gambar 5. Grafik Iradiasi Matahari Setiap Variasi

Kelembapan Udara/RH Lingkungan dan Ruang Pengering

Nilai $\mathrm{RH}$ dalam penelitian diukur dengan menggunakan alat berupa digital environment multimeter 5 in 1 . Hasil pengukuran yang didapatkan dapat dilihat pada Gambar 4.5. Pada percobaan tanpa menggunakan fan $\mathrm{RH}$ 
lingkungan tertinggi pukul 09.00 sebesar sehari sebesar 0,67 kg/jam. Percobaan dengan $69,35 \%$ dan rata-ratanya $60,41 \%$. Untuk variasi menggunakan 1 fan memiliki laju pengeringan dengan menggunakan $1 \mathrm{fan}$, nilai $\mathrm{RH}$ tertinggi pukul 12.00 sebesar $0,97 \mathrm{~kg} / \mathrm{jam}$, lingkungan tertinggi pada pukul 09.00 sebesar terendah pada pukul 15.00 sebesar 0,39 $65,9 \%$ dan rata-ratanya $58,21 \%$. Sementara $\mathrm{kg} / \mathrm{jam}$, dan rata-rata dalam sehari sebesar itu, pengeringan dengan menggunakan cara $0,73 \mathrm{~kg} / \mathrm{jam}$. Sedangkan pada percobaan konvensional menghasilkan nilai $\mathrm{RH}$ tertinggi konvensional, laju pengeringan tertinggi pukul sebesar $71,56 \%$ pada pukul 09.00 , terendah 12.00 sebesar $0,5 \mathrm{~kg} / \mathrm{jam}$, terendah pada pukul pada pukul 13.30 sebesar $54,23 \%$, dan rata- 15.00 sebesar 0,18 , dan rata-rata dalam rata yang dihasilkan dalam pengeringan pengeringan $0,033 \mathrm{~kg} / \mathrm{jam}$. Percobaan dengan sebesar $60,87 \%$.

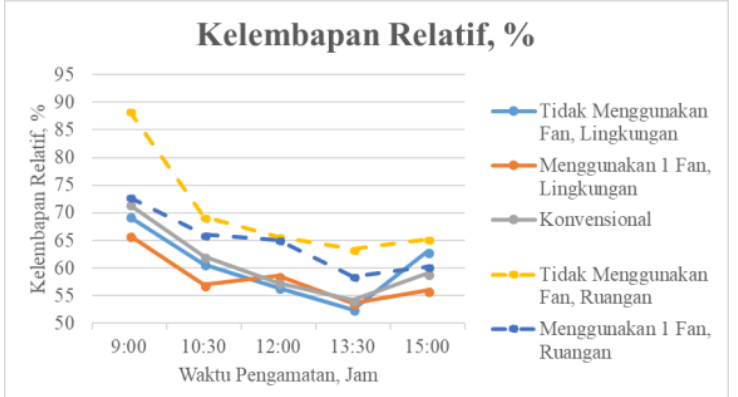

Gambar 6. Grafik Kelembapan Relatif (Relative Humidity/ RH) Setiap Variasi

Gambar 6 menunjukkan hasil pengukuran kelembaban relatif $(\mathrm{RH})$. $\mathrm{RH}$ lingkungan setiap harinya selama percobaan memiliki nilai tertinggi pada pukul 09.00. Hal ini dikarenakan masih belum banyak sinar matahari yang dipancarkan. Kelembaban tersebut akan menurun dan meningkat kembali pada saat pukul 15.00. Sedangkan hasil pengukuran kelembapan/RH pada ruang pengering menunjukkan bahwa $\mathrm{RH}$ ruangan pada percobaan tanpa fan memiliki nilai tertinggi dibandingkan dari percobaan lainnya. Hal ini dikarenakan tidak terdapat proses secara paksa untuk membantu keluarnya udara dan uap air dari pengeringan tersebut.

\section{Laju Pengeringan}

Laju pengeringan merupakan perbandingan antara jumlah air yang dapat diuapkan $(\mathrm{kg})$ dalam selang waktu tertentu. Berdasarkan hasil perhitungan yang dapat dilihat pada Gambar 7, percobaan tanpa fan menghasilkan laju pengeringan tertinggi pada pukul 12.00 sebesar $0,86 \mathrm{~kg} / \mathrm{jam}$, terendah pada pukul 15.00 sebesar $0,49 \mathrm{~kg} / \mathrm{jam}$, dan rata-ratanya dalam
1 fan mempunyai nilai laju pengeringan tertinggi dibandingkan lainnya. Hal ini disebabkan karena fan membantu mensirkulasikan udara panas di dalam greenhouse, sehingga RDF lebih cepat menguapkan kandungan air.

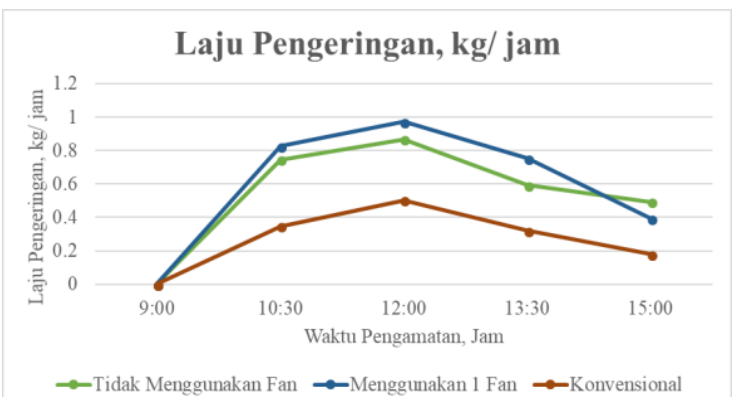

Gambar 7. Grafik Laju Pengeringan RDF Setiap Variasi

\section{Kadar Air Pada RDF Setelah Dikeringkan Dalam Solar Dryer}

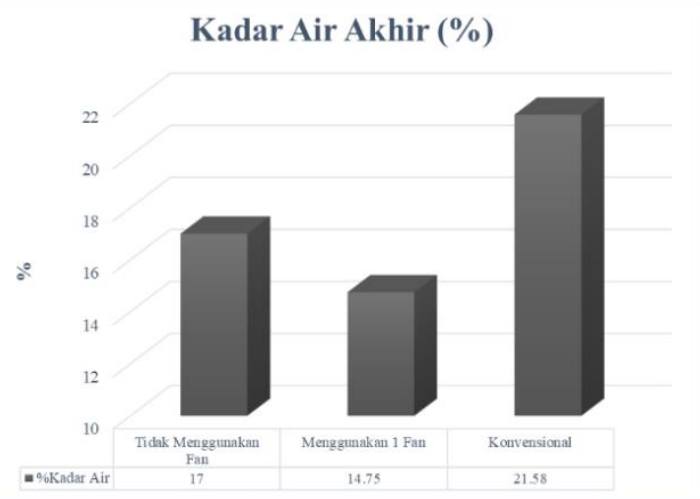

Gambar 8. Grafik Kadar Air Akhir RDF Setiap Variasi

Hasil penelitian menunjukkan bahwa pada percobaan tidak menggunakan fan, kadar air RDF setelah dikeringkan adalah $17 \%$. Pada 
percobaan dengan variasi memakai 1 fan RDF, kandungan air akhir menunjukkan nilai 14,75\%. Sedangkan hasil akhir kadar air dengan pengeringan secara konvensional sebesar $21,58 \%$. Kadar air yang didapatkan dari semua percobaan, pengeringan dengan menggunakan solar dryer ini sudah mencapai standar yang diberikan untuk WTZ yaitu sebesar $10-20 \%$. Percobaan dengan variasi 1 fan menghasilkan kadar air terendah. Hal ini disebabkan karena proses pengeringan dibantu oleh adanya fan yang dapat mensirkulasikan udara panas di dalam greenhouse.

\section{Efisiensi Sistem Pengering}

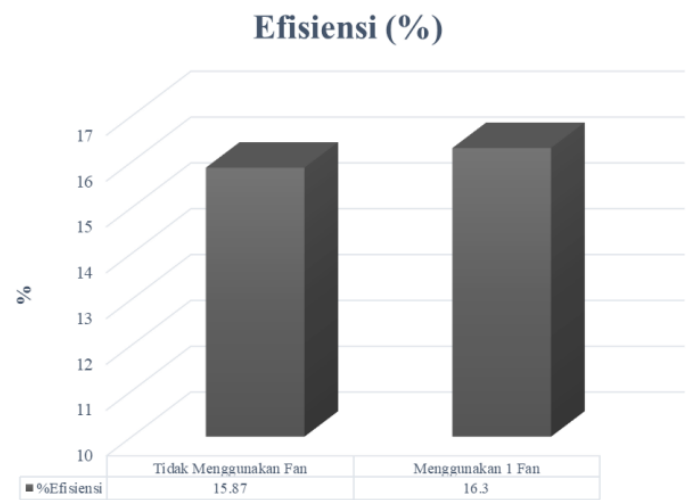

Gambar 9. Nilai Efisiensi Sistem Pengering untuk Variasi Tidak Menggunakan Fan dan Menggunakan Fan

Berdasarkan nilai efisiensi pada Gambar 9, percobaan tanpa menggunakan fan memiliki nilai yang lebih rendah dibandingkan dengan variasi menggunakan fan, yaitu sebesar 15,87 $\%$. Pada percobaan dengan memakai 1 fan menghasilkan nilai 16,3\%.

\section{KESIMPULAN}

Kesimpulan yang diperoleh dalam penelitian alat pengering RDF dengan sistem greenhouse adalah:

1. Laju pengeringan tertinggi dihasilkan oleh system pengering dengan variasi 1 fan, yaitu sebesar $0.73 \mathrm{~kg} /$ jam. Variasi tanpa fan menunjukkan penurunan laju pengeringan sebesar $0.67 \mathrm{~kg} / \mathrm{jam}$. Sedangkan metode konvensional memiliki laju pengeringan sebesar $0.033 \mathrm{~kg} / \mathrm{jam}$.
2. Pengeringan dengan menggunakan solar dryer dapat menghasilkan kadar air sebesar $17 \%$ untuk variasi tanpa fan dan $16,25 \%$ untuk variasi 1 fan. Sedangkan pengeringan dengan cara konvensional menghasilkan nilai kadar air sebesar $21,58 \%$.

3. Alat pengering yang dilengkapi dengan 1 buah fan memiliki efisiensi sistem pengering lebih tinggi dibandingkan dengan alat pengering tanpa fan.

4. Perancangan desain yang cocok untuk mengeringkan RDF adalah solar dryer berbentuk greenhouse tipe tunnel atau trowongan dengan menggunakan variasi percobaan pemakaian 1 fan.

\section{UCAPAN TERIMA KASIH}

Penelitian ini telah didanai dan didukung oleh Direktorat Riset dan Pengabdian Masyarakat (DRPM) Direktorat Jenderal Penguatan Riset dan Pengembangan Kementrian Riset, Teknologi dan Pendidikan Tinggi dalam skema Penelitian Dosen Pemula (PDP) yang berjudul Rancang Bangun Solar Dryer untuk Meningkatkan Kualitas Refuse Derived Fuels (RDF) sebagai Bahan Bakar Alternatif di Kiln Burner Industri Semen.

\section{DAFTAR PUSTAKA}

[1] Ummatin, KK, Yakin, DA dan Ayunina, D. "Analisa Manfaat Biaya Proyek Pembaharuan Unit Pengolahan Sampah Kota Gresik Dengan Teknologi Hydrothermal". Jurnal Industrial Series, Vol. 3, No. 1, pp. 234-239. 2017.

[2] Forson, FK, Nazha, MAA, Akuffo, FO dan Rajakaruna, $\mathrm{H}$, "Design of mixed-mode natural convection solar crop dryers: Application of principles and rules of thumb," Renewable Energy, vol. 32, no. 14, pp. 2306-2319, 2007.

[3] Maiti, Subarna and Patel, Pankaj and Vyas, Kairavi and Eswaran, Kruthika and Ghosh, Pushpito K, "Performance evaluation of a small scale indirect solar dryer with static reflectors during nonsummer months in the Saurashtra region 
of western India," Solar Energy, vol. 85, no. 11, pp. 2686-2696, 2011.

[4] Banout, JAN and Havlik, Jaroslav and Kulik, Michal and Kloucek, Pavel and Lojka, Bohdan and Valterova, Irena, "Effect of solar drying on the composition of essential oil of sacha culantro (Eryngium foetidum L.) grown in the peruvian amazon," Journal of food process engineering, vol. 33, no. 1, pp. 83-103, 2010.

[5] NS Rathore and NL Panwar, "Design and development of energy efficient solar tunnel dryer for industrial drying," Clean Technologies and Environmental Policy, vol. 13, no. 1, pp. 125-132, 2011.

[6] S. Janjai, "A greenhouse type solar dryer for small-scale dried food industries: development and dissemination," International journal of energy and environment, vol. 3, no. 3, pp. 383-398, 2012.

[7] Morad, MM and El-Shazly, MA and Wasfy, $\mathrm{KI}$ and El-Maghawry, Hend AM, "Thermal analysis and performance evaluation of a solar tunnel greenhouse dryer for drying peppermint plants," Renewable Energy, vol. 101, pp. 992-1004, 2017.
[8] O. Ekechukwu, "Review of solar-energy drying systems I: an overview of drying principles and theory," Energy Conversion and Management, vol. 40, no. 6, pp. 593613, 1999.

[9] J. A. Duffie, W. A. Beckman, solar engineering of thermal processes, New York: John Wiley and Sons, 1991.

[10] Bargach, MN and Tadili, R and Dahman, AS and Boukallouch, M, "Survey of thermal performances of a solar system used for the heating of agricultural greenhouses in Morocco," Renewable energy, vol. 20, no. 4, pp. 415-433, 2000.

[11] ASHRAE, Handbook of Fundamentals "American Society of Heating, Refrigerating and Air Conditioning Engineers, New York, 2005.

[12] Jitjack, $K$ and Thepa, $S$ and Sudaprasert, $\mathrm{K}$ and Namprakai, $\mathrm{P}$, "Improvement of a rubber drying greenhouse with a parabolic cover and enhanced panels," Energy and Buildings, vol. 124, pp. 178-193, 2016.

[13] Prakash, Om and Kumar, Anil, "Performance evaluation of greenhouse dryer with opaque north wall," Heat and Mass Transfer, vol. 50, no. 4, pp. 493-500, 2014. 